\title{
An Evaluation of the Greek Banking System over the Period 2009-2019
}

\author{
Anastasios Magoutas' ${ }^{1}$ Panos Chountalas², Dimitris Manolopoulos ${ }^{3}$, Nikolaos Gelardos ${ }^{4}$ \\ ${ }^{1}$ Department of Business Administration, National and Kapodistrian University of Athens, Athens, Greece \\ ${ }^{2}$ Department of Business Administration, University of Piraeus, Piraeus, Greece \\ ${ }^{3}$ Department of Business Administration, Athens University of Economics and Business, Athens, Greece \\ ${ }^{4}$ School of Social Sciences, Hellenic Open University, Patras, Greece \\ Email: amagoutas@uoa.gr,pchountalas@unipi.gr,dmanolop@aueb.gr,nik.gelardos@gmail.com
}

How to cite this paper: Magoutas, A. Chountalas, P., Manolopoulos, D., \& Gelardos, N. (2022). An Evaluation of the Greek Banking System over the Period 2009-2019. Theoretical Economics Letters, 12, 76-97. https://doi.org/10.4236/tel.2022.121005

Received: December 18, 2021

Accepted: January 18, 2022

Published: January 21, 2022

Copyright (C) 2022 by author(s) and Scientific Research Publishing Inc. This work is licensed under the Creative Commons Attribution International License (CC BY 4.0).

http://creativecommons.org/licenses/by/4.0/

\section{(c) (i) Open Access}

\begin{abstract}
With the proliferation of banking distress issues over the last years, empirical literature on systemic banking crises has grown substantially. Yet, studies assessing the antecedents of banking systems' structure within EU peripheral economies are less developed. Here, we use data from 2009 to 2019 and employ annual financial statements of Greece's four systemic banks, to assess the country's banking system. Our analysis is based on two panel data econometric models using ten bank-specific business process performance indicators and four macroeconomic variables. Our findings indicate that the causes of the Greek banking system's collapse can be divided into three categories. The first two include macroeconomic and bank-specific factors, whereas the third category suggests other factors related to the long-lasting financial crisis. Evidence recorded highlights that the main cause of the Greek banking crisis was the accumulated deficits and imbalances of the economy which caused initially a debt crisis followed by a banking crisis. However, the exact causes of the problem seem to be more intricate and have their roots in perennial structural distortions of the Greek economy.
\end{abstract}

\section{Keywords}

Greek Banks, Financial Crisis, Panel Data

\section{Introduction}

The banking sector of Greece has experienced major transformations, extensive deregulation and wide structural reforms, with the most current episode being the recent financial crisis. Over the 1990s, the banking system around the globe 
has been characterized by increased competition, anchored in banks' attempt to address the forces of change in the international financial marketspaces. Economic growth benefitted the financial sector resulting in higher profitability and reduced costs for the majority of the banks operating within the European Area and elsewhere. During this period, deposit withdrawals were, to a great extent, predictable allowing banks' strategic plans and objectives to be projected with considerable accuracy.

Given the links between financial stability and banking crises, if the banking system experiences a surge bankruptcy, this would result in adverse outcomes for the entire economy (Apergis, 2021). The banking sector's reputation would be undermined, the stability of the banking system would be threatened and the entire financial infrastructure could collapse. As a result, the economy would enter in a recession period with-in most cases-unknown outcomes and consequences (Eijffinger \& Karataş, 2020). In order to have a stable and sustainable growth, a country needs to have a strong financial system. Banks, which are the most important actors of the financial systems, play the role of a locomotive to reach these goals (Gökhan \& Esra, 2017). To a great extent, financial crises are interconnected with banking system collapses with detrimental contagious effects to the wider microeconomic and macroeconomic environments. The importance of analyzing the effects of banking crises on the resilience of the economy is an area worth investigation and further research (Kauko, 2014; Jutasompakorn et al., 2014; Pedro et al., 2018; Barrell et al., 2017). This paper constitutes the first attempt, to our knowledge, to assess the causes of the Greek banking crisis that occurred during the international financial crisis of 2008-2009. It specifically aims to explore the endogenous (bank-specific) and exogenous (macroeconomic) reasons of the crisis, taking into account the key performance indicators of the four Greek systemic banks' (i.e. Alpha Bank, Eurobank, National Bank of Greece and Piraeus Bank) derived from their annual financial reports from 2009 to 2019. We consider our research topical; financial market distortions and inefficiencies create imbalances that build up over many years until they reach explosive levels. In that sense, longitudinal analyses of the banking systems provide invaluable insights, having a broad impact on both the microeconomic and macroeconomic levels of countries. Our focus on Greece could trigger research in other economies characterized by similar levels of development and banking systems' maturity.

The remainder of this paper is organized as follows. Section 2 reviews banking business process performance measurement, focusing on the major efficiency studies of the Greek banking system. Section 3 presents the basic characteristics of the Greek banking sector and the weaknesses and distortions which led the system to collapse. Section 4 presents the data sources and the methodological issues of this study and Section 5 interprets the results derived by data analysis. Section 6 summarizes the causes of the Greek banking system collapse, grouped into three categories: macroeconomic factors, bank-specific factors and other 
factors. The conclusions of this study together with some policy implications are presented in Section 7.

\section{Banking Business Process Performance Measurement}

In the literature two main approaches dominate, relative to the banking business process performance measurement. The first approach adopts the side of profitability, measuring the ability of a bank to generate profits; while the second focus on efficiency, measuring how well a bank is using its assets and liabilities in order to generate income. In this study we focus on the financial aspect of business process performance (Kueng, 2000; Van Looy \& Shafagatova, 2016), whereas the analysis of other aspects, such as customer or employee performance, is out of scope of this paper. Most often financial or banking crisis are the result of either poor performance of some financial institutions or of the inefficiency of the entire banking system. Thus, by investigating the level of performance of a banking system, we reveal the weaknesses able to unsettle the system.

The rest of this section reviews both efficiency and profitability studies for the Greek, as well as the international banking sectors. Hondroyiannis et al. (1999), use the Rosse-Panzar statistic over the period 1993-1995 in order to examine the competitive conditions of the Greek banking system. They use as dependent variable of their regression analysis the total revenues to total assets ratio and they regressed on it a variety of internal (banking-specific) variables. They conclude that Greek banks operate under conditions of monopolistic competition while the banking liberalization achieved since early 90s improved the competition among Greek banks. Kosmidou and Spathis (2000), apply a cost-benefit analysis in an attempt to predict the future prospects of the Greek banking system after the introduction of the Euro currency in 2002. They indicate that initially for the 2002-2007 period, the Greek banks were expected to face a loss of profits. However, further analysis indicates that banking profits were expected to increase rapidly in the long run well above the initial losses. Halkos and Salamouris (2004) and Mylonidis and Kelnikola (2005), examine the effect of mergers and acquisitions on the profits, operating efficiency and labor productivity of Greek banks over the period 1999 and 2000. They provide evidence that the mergers and acquisitions had a positive effect on the performance of Greek banks. In addition, Rezitis (2008) indicates that the technical efficiency of banks deteriorated in the short period after the merger while the corresponding technical efficiency of the non-merger banks improved over the same period. Taking additionally into account the competitive conditions of the Greek banking system, they concluded that after the significant mergers and acquisitions that took place in 1998, the merged banks focused on activities in order to increase their market power and gain higher profits rather than on operating efficiency.

Kosmidou and Zopounidis (2008) examined the determinants of Greek banks' performance over the period 1992-2002, during which the domestic banking system implemented all the transitional reforms in order to be properly prepared 
for the integration into the European Union's financial system. The authors used a pooled time series dataset of 23 banks providing evidence that the well capitalized banks achieved high Return on Assets (ROA). Moreover, they found that macroeconomic factors such as Gross Domestic Product (GDP) and Inflation had a significant impact on ROA. Athanasoglou et al. (2008), examine the productivity fluctuations of Greek banks from 1990 up to 2006. They conclude that the increased labor productivity and output of the bank sector, which exceeded those of the Greek economy as a whole, can be attributed to the structural changes of the sector, the investments in ICT products and the improvement of the human capital quality. In addition, in a similar study on Greek banks productivity over the period 1994-2006, Asimakopoulos et al. (2008), suggest that the improvement in management led banks to achieve higher levels of efficiency. Alexiou and Vogiazas (2009) apply a panel data model on the six larger Greek banks over the period 2000-2007. They used quarterly data derived from the annual financial statements of these banks. As dependent variables the used the ROA and Return on Equity (ROE) of the six banks and regressed on them a variety of both internal (bank-specific) and external (macroeconomic) independent variables. According to their results, almost all the bank-specific determinants affect significantly the bank profitability, while the macroeconomic factors seem to be indifferent. Chortareas et al. (2009) provide evidence suggesting that the cost efficiency has increased by $4.3 \%$ over the period 1998-2003, covering Greece's entry into the Euro area and the run-up to it. Moreover, Greek banks seem to enjoy relatively high profit efficiency and productivity.

In a more recent study, Petria et al. (2015), examine the main determinants of banks' profitability in EU27 over the period 2004-2011. They also used bank-specific (internal) and macroeconomic (external) factors in order to define the impact on banks' Return on Average Assets (ROAA) and Return on Average Equity (ROAE). Among others, they concluded that credit and liquidity risk, management efficiency, business diversification, market concentration/competition and economic growth have all a significant impact on both ROAA and ROAE determination. Similarly, Louzis and Vouldis (2015), using data for the same period (2004-2011), estimate the determinants of interest and non-interest income of the Greek banking system. They use panel data which cover the whole Greek commercial banking system. They find that net interest income was affected by banks' market power, operative costs and their ability to diversify their income sources in order to enhancing their non-interest income. The most efficient banks possess a stronger deposit base and have greater leverage able to support their non-interest income. Menicucci and Paoluci (2016), investigate the relation between bank specific factors and profitability in the European banking sector. They apply panel data regression analysis on 35 European banks over the period 2009-2013. They find that banks with higher loan loss provisions deal with lower profitability while banks with higher loan and deposits ratios seem to be more profitable even if the corresponding econometric coefficients were statistically 
insignificant in some cases. Barrell et al. (2017) test for the direct impacts of interest rate liberalization on crisis probabilities and their indirect effects via capital adequacy providing evidence that interest rate liberalization has a crisis reducing effect. Kohlscheen et al. (2018) apply panel data regression analysis using data from 534 banks from 19 emerging economies in the period 2000-2014. They find that a positive relationship between the long run interest rates and profitability while higher short-term rates tend to reduce profits due to raising funding costs. Also, they suggest that credit growth affects profitability more than GDP growth when the banking sector operates in normal times.

\section{The Greek Financial Crisis}

Many terms have been used to describe what happened to the Greek economy since 2008, such as: "the Greek debt crisis", "the Greek financial crisis" or "the Greek banking crisis". Usually, this terminology indicates spiral negative shock in the economy. For instance, a banking crisis can be the result of a financial crisis, as banks are affected directly by a sudden plunge of one or more financial factors. Such a factor could be the extreme exchange rate instability, a rapid drop of stock prices or a sovereign debt shock as has been the Greek case in 2009. So, the fear of an uncontrolled Greek debt caused a debt crisis; the debt crisis led to a financial crisis, which in turn created a banking crisis. In this section, the determination of the origins of the Greek debt crisis is briefly analyzed. The identification of the roots of the Greek debt crisis is expected to contribute significantly to the determination of the causes of the Greek banking collapse that took place between 2009 and 2019.

During the 80s and 90s, the Greek economy was suffering from high inflation rates around $20 \%$, similarly high interest rates, large fiscal and external imbalances and balance of payment instabilities. Since 2001, with the introduction of the Euro currency, the Greek economy underwent a transformation according to the European standards and as result, between 2001 and 2008 the real growth averaged almost $4 \%$ per year, the inflation dropped to the European average and the 10-year bond's spread reduced in the region between 10 and 50 basis points from over 600 in the late 90's (Provopoulos, 2014).

Figure 1 shows that the Greek 10-year bond yield was circa 5\% until 2009, and then it started to rise and soared in 2012-2013 reaching an extraordinary 37\% banning Greece from the international financial markets, as Greek sovereign debt lost its credibility and became an extremely risky investment.

Figure 2 provides strong evidence that the Greek economy was performing with limited responsibility for a long time. The limit of the governmental budget deficit set by EU was 3\% of GDP. As the figure depicts, Greek governments violated the EU condition by spending diachronically more than the threshold. After all, the spark which lit up the fire of the Greek financial crisis was the announcement of a huge governmental budget deficit in 2009 equal to $15.20 \%$ of Greek GDP. 


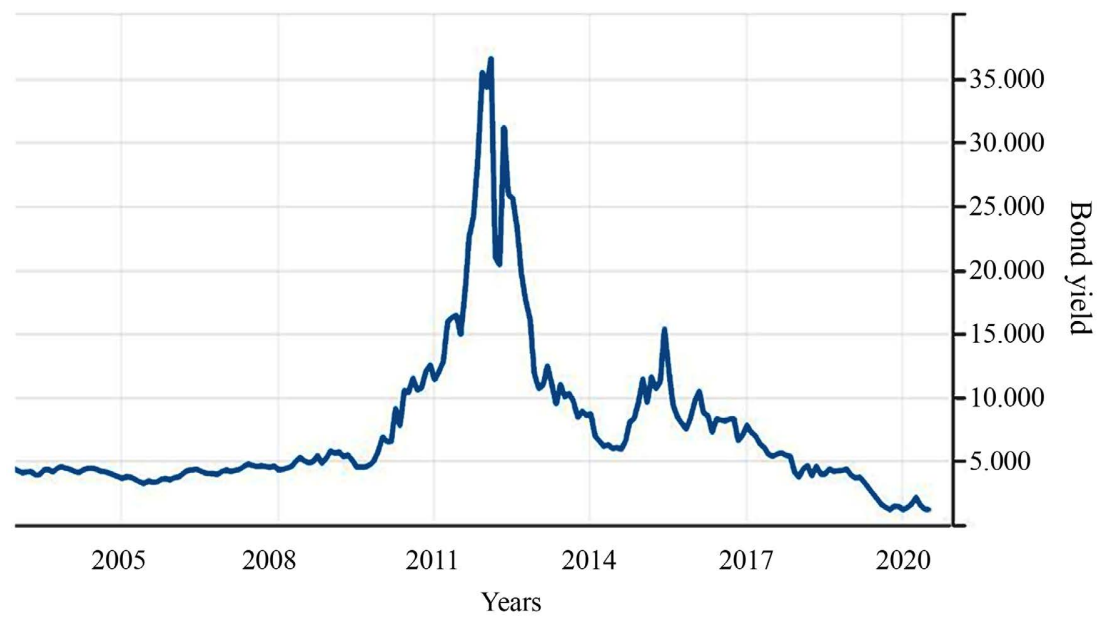

Figure 1. Greece 10-year bond yield (Source: tradingeconomics.com).

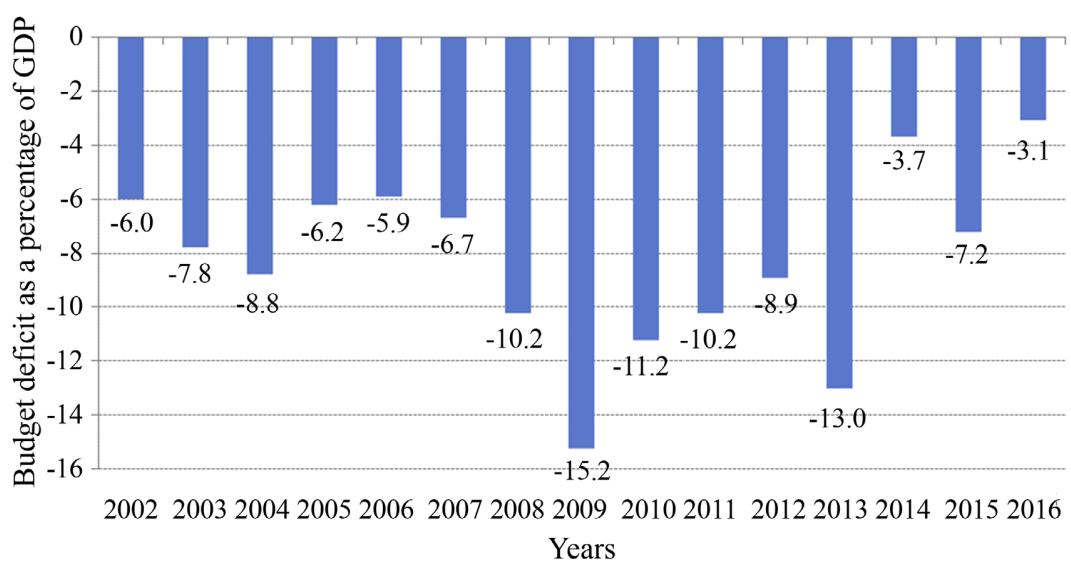

Figure 2. Greek government budget deficit as a percentage of GDP (Source: Eurostat).

The GDP growth rate which was around $4 \%$ since Greece joined the Euro area, dropped rapidly after 2008 and reached a low in 2011 at $-9.13 \%$, as depicted in Figure 3. Finally, the Greek sovereign debt as percentage of GDP (Figure 4) has been always higher than $100 \%$ of GDP, well above the limit of $60 \%$ that had been set by EU. Between 2009 and 2011 it was slightly reduced due to write offs of a part of private sector's contribution on public debt haircut (PSI). But, during the following years, it increased again sharply to be stabilized near $195 \%$ of GDP.

Finally, Figure 5 plots the variance of the Greek current account deficit. It is clear that the Greek governments and the Bank of Greece lost control as the deficit reached a high peak in 2008 exceeding 14\%.

The above-mentioned indicators are highly correlated to each other. Deficits create a gap between incomes and expenditures. These gaps are usually covered with new loans. The new loans aggravate the debt to GDP ratio and finally bonds spread increases making new loaning more expensive till the moment a debt crisis starts. Additionally, Provopoulos (2014) suggests that there were two main 


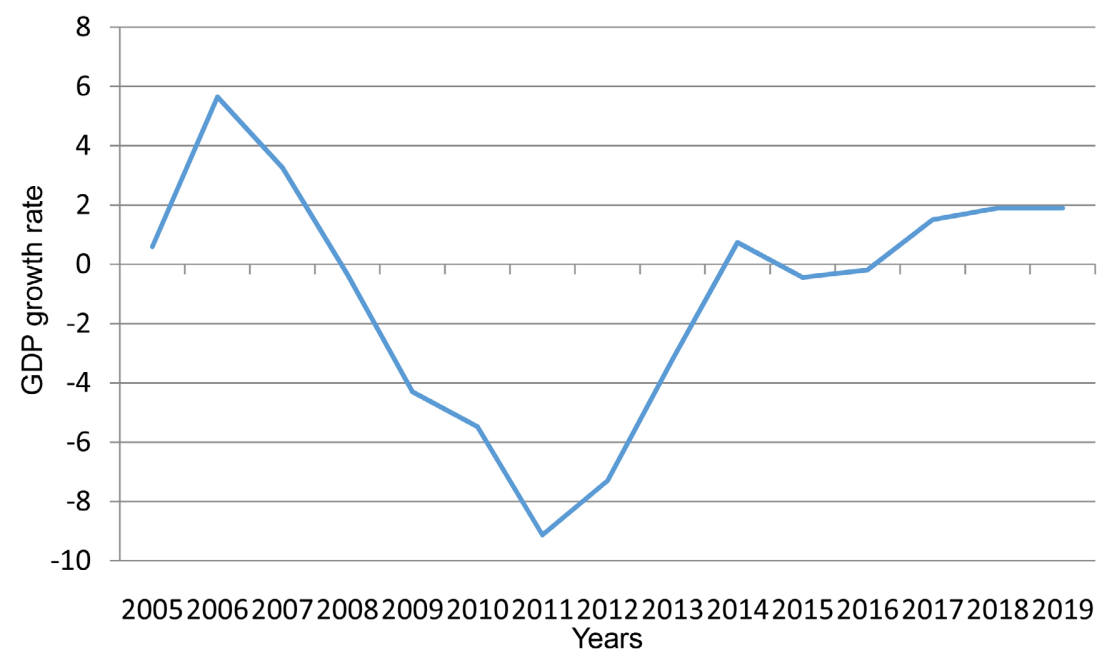

Figure 3. Greek GDP growth rate (Source: OECD Database).

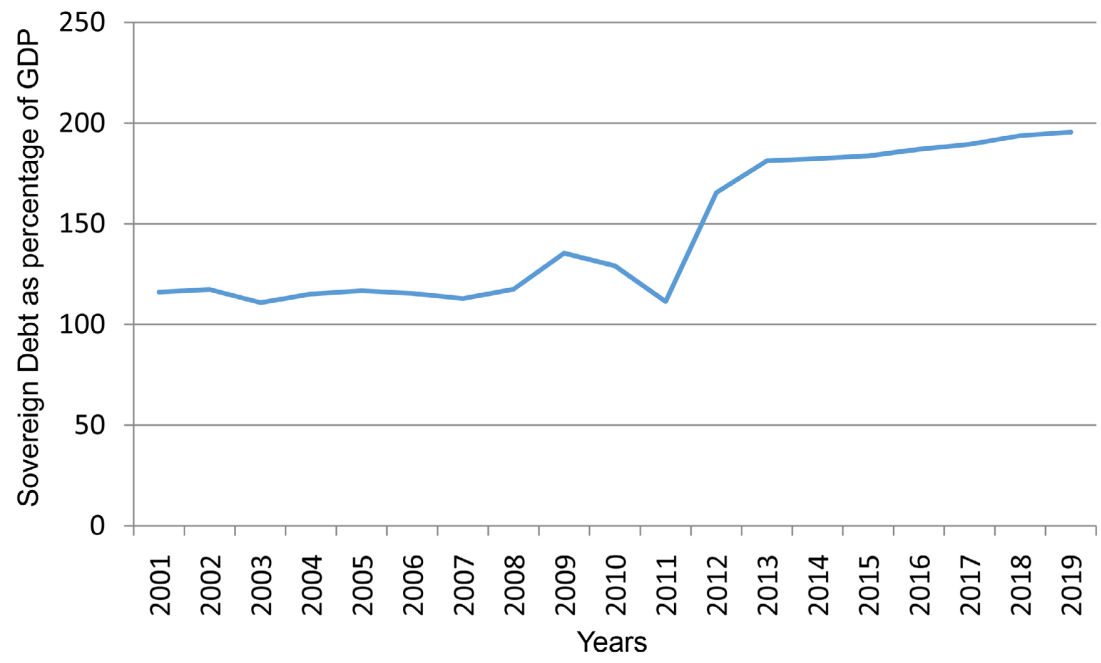

Figure 4. Greek sovereign debt as percentage of GDP (Source: OECD Database).

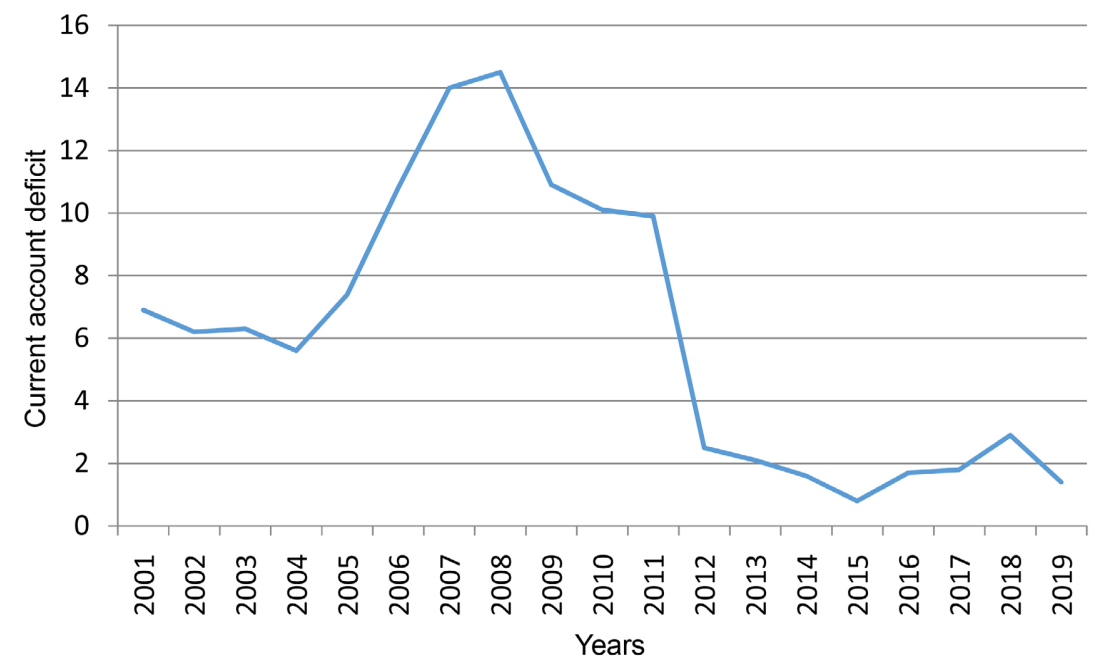

Figure 5. Greek current account deficit (Source: World Bank statistics). 
reasons responsible for the peculiarities of Greek crisis. Firstly, the Greek crisis was sparked by the country's public sector imbalances, as opposed to other European countries where the private sector was found responsible. Secondly, in the case of Greece, the sovereign debt crisis spilled over to the banking sector and caused its collapse. Conversely, in the majority of the European countries, the economic crises hit initially the banking sector and the sovereign sector has ensued. To conclude, Figures 1-5 highlights the structural problems of Greek economy and as Provopoulos (2014) states, "all these imbalances meant that Greek crisis was just an accident waiting to happen".

\section{Data and Methodological Issues}

\subsection{The Data Set}

This paper uses annual data collected from the four systemic Greek banks together with the most important macroeconomic indicators. We extract the data from the official published financial statements of the banks while the macroeconomic variables were collected from databases such as OECD, World Bank and the Hellenic Statistic Service (ELSTAT). The data cover a period of eleven years between 2009 and 2019 (i.e., the period that the Greek crisis started, peaked up and finally normalized). The data transformed to specific banking business process performance indicators which cover a wide range of banking efficiency such as assets quality, capital, operations and liquidity (Balaban et al., 2011; Bosilj-Vuksic et al., 2008; Hernaus et al., 2012; Vom Brocke, 2007; Wu, 2012). More specifically, the following indicators were accrued and used in the construction of the econometric models of the present study:

1) TR/TA: total revenues to total assets ratio (i.e., the asset turnover ratio) is a measure of bank performance. The higher the TR_TA ratio, the more intensively a bank uses its assets in order to generate income. TR_TA can be used as dependent variable in econometric models in order to estimate the competition among companies (Hondroyiannis et al., 1999).

2) ROE: return on equity is one of the most commonly used key ratios for the determination of a bank's profitability. It measures the net benefit shareholders get by investing their capital in a financial institution. The majority of economists use ROE as dependent variable in their econometric models, trying to investigate banking profitability (Sayilgan \& Yildirim, 2009).

3) EQ/TA: equity to total assets ratio is a determinant of bank's level of leverage. A high $\mathrm{EQ} / \mathrm{TA}$ ratio means that the bank is able to substitute debt with equity shares. It is expected to exert positive influence on TR/TA and ROE.

4) T1R: tier 1 ratio measures a bank's solvency. It is determined as the bank's tier 1 capital (mainly shareholders' stock and retained earnings) to risk-weighted assets. According to Basel II agreement, the minimum tier 1 capital requirement of a bank is $8 \%$.

5) $\mathrm{PE} / \mathrm{OI}$ : personnel expense to operative income ratio is a determinant of operating costs. The lower the PE/OI the better a bank uses its human resources. 
It is expected to affect negatively the TR/TA and ROE.

6) NIM: net interest margin is a profitability indicator and it is defined as the difference between the interest a bank provides loans and the interest the same bank pays to its depositors. It is expected to affect both TR/TA and ROE positively.

7) NPL: non-performing loans ratio is an indicator of a bank's loan quality. A low NPL is evidence that bank's unpaid loans for longer than 90 days are kept under control and within predefined limits. The NPL is expected to affect negatively the TR/TA and ROE.

8) NL/DE: net loans to deposits ratio is an indicator of a bank's liquidity. High NL/DE means that the bank may not be able to cover unexpected fund requirements as its loans exceed the deposits by far and expose bank in increased credit risk. From the other side, a very low NL/DE may express that the bank does not use its deposits efficiently and as result the bank loses earnings.

9) NL/TA: net loans to total assets ratio is a measure of a bank's liquidity. The higher NL/TA ratio the lower the bank's liquidity is. Additionally, lower liquidity means that the bank operates in higher risk as loans are not easily liquidated.

10) LLR/GL: loan loss reserves to gross loans ratio is an indicator of a bank's assets quality. The higher the LLR/GL ratio the better a bank is able to deal with its problematic loans.

11) PERS: is the number of each bank's domestic personnel.

12) BRAN: is the number of each bank's domestic branches.

13) EXT/DEBT: is a macroeconomic indicator and is defined by the volume of Greece's external debt.

14) GDPCAP: is a macroeconomic indicator which determines a country's welfare.

15) UNEPL: is the country's annual unemployment rate.

16) PRV/CONS: reflects country's annual private consumption.

All variables are expressed in their natural logarithm form with only exception ROE which is expressed in its actual form as it includes negative values.

\subsection{Econometric Methodology}

In order to address our research purpose, an underlying objective of this paper is to examine the competitiveness and productivity of the Greek banks. These factors, in combination with facts occurred in the Greek banking system during the last decade will help to derive conclusions about the causes of the Greek banking sector's collapse. The generalized form of panel data is the following:

$$
Y_{i, t}=a_{i}+b_{i} X_{i, t}+\varepsilon_{i, t}
$$

where $Y$ is the dependent variable of bank $i$ in time $t$, $a$ is a scalar of bank $i, b_{i}$ is the vector of coefficients of bank $i, X_{i, t}$ is the variable of bank $i$ in time $t$, and $\varepsilon_{i, t}$ is the disturbance term of bank $i$ in time $t$. According to Hsiao (1985) and Klevmarken (1989), the panel data analysis could be performed better than other 
econometric models as panel data: 1) suggest that individual countries etc. are heterogeneous; 2) give more information, more variability, less collinearity among other variables, more degrees of freedom and more accuracy; 3) can capture and measure effects that are not detectable in cross-section time-series analysis, as well as provide a platform on which to test more complicated behavioral models.

We use two different pooled panel regressions. The first, uses as dependent variable the TR/TA as it reflects the banking market forces. A set of nine dependent variables is regressed on TR/TA. The seven of them, are bank specific variables while the rest two are macroeconomic indicators and it is expressed by the following equation:

$$
\begin{aligned}
T R / T A_{i, t}= & \beta_{0}+\beta_{1} E Q / T A_{i, t}+\beta_{2} P E / O I_{i, t}+\beta_{3} E X T / D E B T_{i, t}+\beta_{4} N P L_{i, t} \\
& +\beta_{5} \text { EES }_{i, t}+\beta_{6} \text { BRAN }_{i, t}+\beta_{7} \operatorname{GDPCAP}_{i, t}+\beta_{8} N I M_{i, t} \\
& +\beta_{9} N L / D E_{i, t}+\varepsilon_{i, t}
\end{aligned}
$$

Similarly, a set of thirteen independent variables is regressed on ROE. The nine of them are bank specific and the other four are macroeconomic indicators. The second panel data regression is expressed by the following equation:

$$
\begin{aligned}
R O E_{i, t}= & \beta_{0}+\beta_{1} E Q / T A_{i, t}+\beta_{2} E X T / D E B T_{i, t}+\beta_{3} N P L_{i, t}+\beta_{4} U N E P L \\
& +\beta_{5} B R A N+\beta_{6} P R V / C O N S_{i, t}+\beta_{7} G D P C A P_{i, t}+\beta_{8} L L R / G L_{i, t} \\
& +\beta_{9} N I M_{i, t}+\beta_{10} N L / D E_{i, t}+\beta_{11} N L / T A_{i, t}+\beta_{12} P E / O I_{i, t} \\
& +\beta_{13} T 1 R_{i, t}+\varepsilon_{i, t}
\end{aligned}
$$

\section{Results}

Table 1 illustrates the output of the first regression model (i.e., with TR/TA as the dependent variable). Based on the t-statistic values we conclude that all coefficients are statistically significant at the 0.01 level of significance with the exception the PE/OI ratio and EXT/DEBT. The corresponding R-square value is $82 \%$, high enough to conclude that the model's selected independent variables explain adequately the TR/TA ${ }^{1}$.

Contrary to the majority of researchers who suggest that banking efficiency and profitability is independent of the GPD business cycle (Alexiou \& Vogiazas, 2009), the outcome of the above regression suggests that the GDP per capita (GDPCAP) affects significantly and positively the TR/TA ratio. Thus, there is evidence that some macroeconomic figures affect banking efficiency. Regarding bank-specific variables, all estimators are highly significant. The coefficient of EQ/TA ratio has a positive sign, suggesting a co-movement between equity and total revenue (as both ratios have the total assets as a common denominator). As expected, the PE/OI ratio affects negatively TR/TA since higher personnel expenditures relatively to the operative income of a bank are usually correlated with insufficiencies on human resource utilization. The number of personnel ${ }^{1}$ Additionally, a Wald test is applied in order to reject the null hypothesis that all coefficients are equal to zero. 
Table 1. Estimation results: Dependent variable TR/TA.

\begin{tabular}{ccccc}
\hline Variables & Observed Coefficients & Std. Errors & $t$-Statistics & Prob \\
\hline EQ/TA & $0.180838^{* * *}$ & 0.063483 & 2.848 .596 & 0.0081 \\
PE/OI & $-0.264801^{*}$ & 0.133896 & -1.977 .668 & 0.0579 \\
EXT/DEBT & 0.369182 & 0.231791 & 1.592 .738 & 0.1224 \\
NPL & $0.318632^{* *}$ & 0.103515 & 3.078 .136 & 0.0046 \\
PERS & $0.907266^{* * *}$ & 0.173158 & 5.239 .534 & 0.0000 \\
BRAN & $-1.182240^{* * *}$ & 0.197301 & -5.992 .075 & 0.0000 \\
GDPCAP & $1.843276^{* * *}$ & 0.370179 & 4.979 .419 & 0.0000 \\
NIM & $0.654704^{* * *}$ & 0.154677 & 4.232 .708 & 0.0002 \\
NL/DE & $1.002075^{* * *}$ & 0.177192 & 5.655 .311 & 0.0000 \\
Constant & $-28.66885^{* * *}$ & 5.063 .660 & -5.661 .685 & 0.0000 \\
\hline
\end{tabular}

Note: ${ }^{*},{ }^{* *},{ }^{* *}$ indicate significance at $10 \%, 5 \%$ and $1 \%$ levels, respectively. R-square $=$ $82 \%$.

(PERS), on the other hand, contributes positively to the banking efficiency contrary to the number of branches (BRAN) which affects negatively the TR/TA ratio. This is probably demonstrates an indirect effect of the extensive mergers and acquisitions that took place among Greek banks since 2012. Although, the four systemic banks absorbed through mergers and acquisitions an important number of skilled staff able to improve banking efficiency, still the banks found themselves with an extraordinary surplus of branches across the country. After the mergers and acquisitions, it was common practice for the banks to operate in excess of branches even in cities with low population numbers. It should be noted that this finding is opposite Hondroyiannis' (1999) positive relation between the number of branches and banking efficiency.

Moreover, positive and significant is the correlation between the non-performing loan ratio (NPL) and TR/TA. A bank's NPLs, affect TR/TA in two ways. First, as NPLs increase, the quality of bank's assets decreases resulting in the gradual fall of assets' value. Second, banks due to economic strangulation because of the crisis, reoriented their priorities towards non-interest activities. As we know, the main resource of a bank's interest income comes from its loan portfolio. The Greek banks found themselves in the difficult position to be unable to provide new loans to their customers. As a result, the total assets shrank and the TR/TA ratio increased. As expected, the net interest margin (NIM), affects significantly and positively the TR/TA ratio. The lack of liquidity pushed the Greek banks to restrict their NIMs. Their attempts to renegotiate the NPLs with their customers for longer repayment periods and higher interests failed. In addition, banks tended to keep their deposit interest as high as possible in an attempt to attract new depositors and support their liquidity. The effect of the net loans to deposits 
ratio (NL_DE) is also significant and positive. Obviously, due to the extensive withdrawals that occurred within the crisis period, the Greek banks' NL_DE ratios were affected negatively and, in most cases, they reached the abnormal $150 \%$. Thus, the positive relation between TR_TA and NL_DE is explained by both ratios' denominators decline. The results of the second regression equation are reported in Table 2. The ROE ratio is widely used as an indicator of banking profitability. Thus, by examining the affiliations between ROE and the selected bouquet of independent variables, we could derive significant conclusions relative to the Greek banking system's behavior during the 2009-2019 crisis.

It should be noted that the four macroeconomic indicators used as independent variables have coefficients statistically significant at $1 \%$. Almost all bank-specific coefficients are insignificant with the exemption of the equity to total assets ratio (EQ/TA) and tier 1 ratio (T1R). However, the selected variables determine well enough the ROE as the R-squared value is near $90 \%{ }^{2}$.

Thus, an obvious comment we can easily make from the above results is that banking profitability was affected in a high degree by Greece's macroeconomic environment. However, three out of four macroeconomic variables have coefficients with signs different than what the theory suggests. The external debt (EXT/DEBT) and unemployment rate (UNEPL), seem to affect ROE positively while the GDP per capita (GDP_PER_CAP) shows a reverse situation. Only the

Table 2. Estimation results: Dependent variable ROE.

\begin{tabular}{ccccc}
\hline Variables & Observed Coefficients & Std. Errors & $t$-Statistics & Prob \\
\hline EQ/TA & $1.825503^{* * *}$ & 0.287579 & 6.347841 & 0.0000 \\
EXT/DEBT & $8.480406^{* * *}$ & 1.414848 & 5.993862 & 0.0000 \\
NPL & 0.808556 & 0.795705 & 1.016150 & 0.3211 \\
UNEPL & $6.222550^{* * *}$ & 1.415909 & 4.394737 & 0.0003 \\
BRAN & -0.606037 & 0.592322 & -1.023155 & 0.3179 \\
PRV/CONS & $54.01799^{* * *}$ & 12.55083 & 4.303937 & 0.0003 \\
GDPCAP & $-12.35969^{* * *}$ & 3.465623 & -3.566370 & 0.0018 \\
LLR_GL & 0.187468 & 0.630114 & 0.297515 & 0.7690 \\
NIM & 0.121523 & 0.648499 & 0.187391 & 0.8532 \\
NL/DE & -1.576093 & 1.268239 & -1.242741 & 0.2277 \\
NL/TA & $-1.317076^{*}$ & 0.757453 & -1.738823 & 0.0967 \\
PE/OI & -1.045988 & 0.918481 & -1.138824 & 0.2676 \\
T1R & $-2.435974^{* * *}$ & 0.665798 & -3.658727 & 0.0015 \\
Constant & $-685.728^{* * *}$ & 141.5773 & -4.369151 & 0.0003 \\
\hline
\end{tabular}

Note: ${ }^{*}{ }^{* *},{ }^{* *}$ indicate significance at $10 \%, 5 \%$ and $1 \%$ levels, respectively. R-square $=$ $89 \%$.

${ }^{2}$ Wald rejects the null hypothesis that all coefficients are equal to zero. 
private consumption's (PRV_CONS) coefficient has a sign according to the theory. A possible explanation is that almost all systemic banks faced for at least one-year negative equity. Additionally, ROE's volatility remained too unstable during all the study period reaching in many cases extreme values (circa 2000\%).

Our finding that the Greek banking profitability affected by country's macroeconomic environment is in line with that of Petrakis (2012) who suggests that the macroeconomic factors were the main cause of the Greek banking crisis. From the bank-specific variables side, the coefficients of T1R and EQ/TA provide evidence that ROE is highly affected by the banks' capital quality. Particularly, the EQ/TA ratio is statistically significant and positive and suggests a positive relation between capital quality and banking performance as many studies suggest (Kosmidou, 2008; Berger, 1995; Demirguc-Kunt \& Huizinga, 1999; Abreu \& Mendes, 2001). The rest of the bank-specific variables are insignificant and not able to determine ROE satisfactorily, although, the signs of the personnel expenditures to operative income ratio (PE/OI) and the number of branches (BRAN) are in line with the outcome of the first regression equation.

\section{Summarizing the Causes of Greek Banking Sector Collapse}

In this section we combine the data presented in the previous analysis in order to derive conclusions about the causes of the Greek banking system's collapse. The econometric models presented in the previous section, suggest both macroeconomic and bank-specific factors responsible for the Greek banking effectiveness. Thus, the determinative factors of the crisis presented here are categorized into three groups. The first comprises the macroeconomic factors, the second includes the bank-specific factors and the third group presents other factors related to ethical, political and social issues.

\subsection{Macroeconomic Factors}

Greece, till 2007, was running a period of economic growth of around of $4 \%$ per year on average as expressed by the increase of the country's annual GPD. However, the Greek economic development for approximately four decades was based on excessive consumption. However, this excessive consumption without the corresponding growth in production creates deficits on the basic macroeconomic factors. Probably, the worst factor for the Greek economy was the expenditures of the central government. During the pre-crisis period, all the governments failed to have a balance in national expenses in order for the State to fulfill its functional obligations. The accumulated budget deficits were increasing diachronically the country' public debt which by the end of 2008 had reached the level of $107 \%$ of GDP. At this point, we must clarify that external debt is not only the amount of money Greece owes to different lenders around the world. The external debt is determined also by: 1) its maturity, 2) its evaluation by the international rating agencies, 3) the derivative financial products connected with the debt, and 4) the spread between the Greek and German bonds. 
Greek crisis began with the announcement of a huge budget deficit of approximately $16 \%$ of GDP. A few months later, Greece admitted an increased possibility of default, or, in other words, the country would be unable to fulfill its future debt obligations. The rapid drop of the 10-year Greek bond value affected directly the assets quality of the Greek banks. The banks were obliged by the Bank of Greece to hold Greek governmental bonds as a proof of their capital adequacy. But, as the Greek bonds were losing their value, the banks' assets were affected negatively too. According to our estimated models, there is evidence that the external debt (EXT/DEBT) affected positively our dependent variables (TR/TA and ROE). We could provide two possible explanations with regard to this result. First, the positive sign of EXT/DEBT's coefficient is a result of ROE's extreme values between 2012 and 2013. ROE dropped abruptly within a year while for the same period EXT/DEBT was fluctuating around a constant value because of both the Private Sector Involvement (PSI) program which depleted somehow the external debt and the bailout programs which burdened debt. Secondly, a significant part of the bailout programs was spent as financial support to the Greek banks. The financial assistance that Greek banks received from the State, improved both the TR/TA ratio and the ROE.

In addition, the external debt affected the Greek banks indirectly too. The announcement of a possible default threatened the depositors who immediately ran massively to withdraw their deposits held by Greek banks. Due to massive withdrawals, banks faced a tremendous strangulation of their liquidity position. Actually, through withdrawals, banks lost all cash they held. In a vain attempt to prevent withdrawals, banks increased gradually their deposit interest. Specifically, the average deposit interest reached a peak between 2009 and 2012. As a result, the Greek banks, during the crisis period were competing with each other for attracting deposits rather than any other financial product.

The contribution of the remaining macroeconomic factors to the Greek banking collapse seems to be negligible. The results of GDPCAP support the argument of a correlation between banking performance and economic growth. As Kosmidou (2008) states about the pre-crisis period, the relation between GDP and banking performance is a result of the Greek macroeconomic environment which operated for a long time under conditions of relative high GDP growth.

\subsection{Bank-Specific Factors}

Through the bank-specific factors examination we attempt to detect weaknesses and possible inefficiencies within the Greek banking system. These factors in combination with external to banking system factors expose banks to a high risk by eliminating banking efficiency and increasing costs. According to our findings based on the econometric models, the banks with higher capital adequacy (as expressed by the EQ_TA ratio) have a competitive advantage over the rest of the banks. They used to face lower risk of going bankrupt and as a result these banks' cost of lending is lower (Kosmidou, 2008). 
On the other hand, the capital adequacy of the four systemic banks was achieved with governmental financial support via recapitalization programs which cost approximately $€ 50$ billion. In other words, the Greek banks were rescued by the State with funds that were lent from the international institutions (EU, IMF, ECB) under strict conditions. However, by borrowing nearly $€ 50$ billion in order to rescue the country's banking system from a total collapse, the Greek external debt was even more burdened. Considering also that the external debt was the main cause of the domestic crisis, we could conclude that the banks' recapitalization had two different impacts on Greek banks. On the one hand, the banks' capital position improved, but on the other, Greece's debt position and by extension the Greek banking system, which is highly related to the Greek debt, remained trapped to operate under restrictions set out by external to Greece decision making centers. Additionally, the significant cost of banks' recapitalization was the reason that only the four biggest banks were rescued. The rest of the banks were left helpless to search for private funds in order to fulfill the new capital adequacy requirements, and as the majority of them failed to do so, they were led to liquidation. As a result, the Greek banking sector shrank desperately, the foreign banks that had been operating in Greece exited the market resulting in an oligopolistic competition similar to that of the previous three decades.

Another bank-specific factor which threatened and still does the Greek banking system is the evolution of the non-performing loans (NPLs). We have already confirmed the statistically significant relation between TR/TA ratio and NPLs. However, the positive relation between them seems rather odd. A possible explanation might be that during the first years of crisis, the TR/TA ratio dropped to extremely low values (near $0.5 \%$ ). We suggest that a further drop to lower levels was impossible and the only option was that ratio's gradual recovery while simultaneously NPLs were increasing too. Thus, we conclude that the positive relation was a result of the increasing of both variables since 2012 when TR/TA ratio plunged to the lowest level. The most important problem of the Greek banking system is possibly the NPLs. Since the beginning of the crisis, the NPLs ratio increased from $5.2 \%$ in 2009 to $49 \%$ in 2016 . This abnormal increase is evidence that banks were providing loans without the corresponding guarantees and furthermore, they were operating for a long time with high-risk loan portfolios. Also, it seems that the beginning of crisis was a good opportunity for many borrowers to stop paying their loans. The reasons of such a behavior will be discussed in the next section.

In addition, as the banks were unable to provide new loans due to their liquidity strangulation caused by the massive withdrawals, they reoriented their activities to deposit products. During the whole crisis period, banks in an effort to attract new funds were advertising time deposits. The increase on average deposit interest reduced banks' net interest margins and furthermore, the banks' profit margins. As result, Greek banks entered into a period of accumulated tax losses. 
The ability of the bank managers to adopt their operating plans to the new circumstances was another significant factor which affected the banks' survival amidst the crisis. The human resources, especially in a crisis period, must be exploited by the most effective way. According to personnel expenses to operating income ratio (PE/OI), the less the $\mathrm{PE} / \mathrm{OI}$ the higher the banking efficiency is. Additionally, the number of employees and branches a bank retains plays a considerable role in banking efficiency. The Greek banks during the crisis, were forced to reduce both their staff and branches in an attempt to keep their operative costs as low as possible. Especially, after the mergers and acquisitions that took place between 2012 and 2015, banks were obliged by the supervising authorities to reduce rapidly personnel mostly via retirement programs as well as their number of branches since after the mergers and acquisitions, all systemic banks were found with an excess number of branches across Greece. However, even though the banks proceeded with branch closures relatively fast, this was not reflected in the reduction of the number of employees working in these branches.

\subsection{Other Factors}

Apart from the factors that have already been discussed there are other factors which we cannot easily estimate by using econometric models or other parametric or non-parametric techniques. In this section, we approach the Greek banking system collapse from the angle of ethical, political and social aspects.

Moral hazard is a fundamental factor hidden behind each crisis. According to Heffernan (2005), the moral hazard arises whenever an agreement between two parties alters the incentives structure of either party. So, moral hazard, could arise from both parties of an agreement, banks (as lenders) or customers (as borrowers). In case of a loan, the moral hazard pushes a lender to search for the investment/loan with the higher return in order to achieve profit maximization. However, a high return investment usually, is accompanied by higher risk. As a result, the banks (especially in periods of economic growth) demand a higher risk premium for loans which normally should be rejected. Something similar have happened in the case of Greece. The Greek economic growth, prior to the crisis, led the Greek banks to provide risky loans (mostly investing and consuming loans) in order to generate more profits by exploiting the increased liquidity that banks had achieved due to the economic circumstances. Unfortunately, many of those loans granted generously before crisis, were converted to NPLs during the crisis.

The problem of moral hazard is aggravated if the borrowers deem that the loan agreement could be changed because of unexpected economic conjuncture as result of an economic recession. The negative effects produced by an economic recession could be used as an excuse by the borrower's side to evade his/her debt obligations. The problem is getting worse if the borrower feels somehow protected from the implications of not paying his/her loan, as it had 
happened in the case of the mortgage loans of the Greek banks. Social criteria forced the Greek governments to protect the borrowers who were unable to pay their mortgages and they were found under the threat of losing their residence. However, it is a usual practice for many borrowers to stop paying their mortgages even if they were able to. For Greece, the results were catastrophic. Firstly, almost $50 \%$ of the borrowers left their mortgages to turn red (NPLs), and secondly, and probably worse in the local context, the notion of mortgage as a fundamental stone of the capitalistic economy has been set back. The most common form of a loan guarantee is the mortgage. Since the majority of mortgages in Greece are under State protection, new mortgages were provided with high difficulty and as result the absence of new mortgages decelerated the rhythm of the economic recovery.

The political intervention is another factor with significant involvement in the Greek banking crisis and its effectiveness is not easily measurable. It seems that in the case of Greece, the political intervention during the crisis made things worse. Eight different governmental schemes have ruled the country during the last decade and this is strong evidence of the political instability in Greece. Figure 6 depicts the political stability index of Greece between 2003 and 2019. According to these results, the political stability in Greece reached a low point in 2015 when the recently elected government decided to renegotiate its agreements with the international institutions (EU, IMF, ECB). The lockdown of the banks and the system's collapse was, in part, the aftermath of the failure in negotiations.

\section{Conclusion}

Since behavioral contexts are determinant in shaping economic activity, crises will inevitably occur. A banking crisis is a recurrent phenomenon and usually signals the end of a period of economic growth (Khan \& Dewan, 2014). During

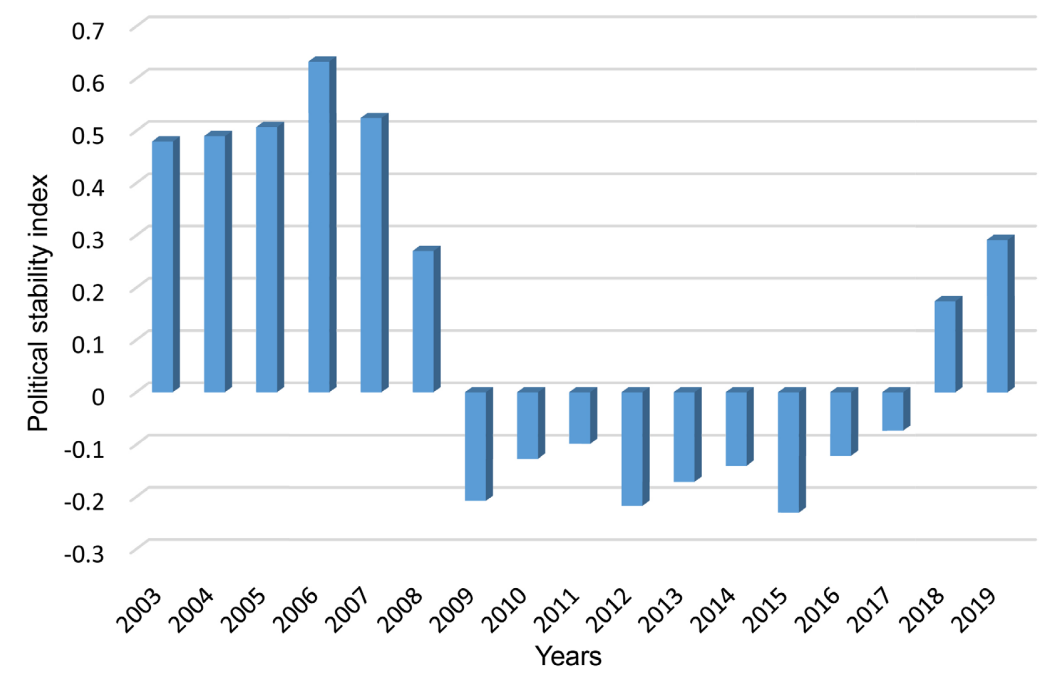

Figure 6. Political stability index of Greece (Source: World Bank statistics). 
the last decade, the Greek banking system suffered from increased instability. There were times (e.g., 2012 and 2015) where no correction theories and policies could be implemented and no one was able to deliver a safe prediction about the future. In other words, the Greek banking system was found in uncharted waters.

The common belief is that banking crises come as a result of endogenous to the banking systems factors. Without having the intention to argue against this perspective, in the case of Greece our econometric models applied suggest rather the opposite. The main cause of the Greek banking system collapse seemed to be the macroeconomic condition of the country as a whole. The structural economic problems of the country since the 80 s have created deficits and imbalances on the main macroeconomic indicators. These deficits and imbalances were attempted to be covered diachronically with accumulation of new debt. In 2008, the accumulated public debt exceeded 107\% of GDP and in combination with the ongoing international financial crisis created an irreversible situation for the Greek economy, and by the end of 2009 Greece was officially suffering a debt crisis. Most often, a debt crisis is reflected mainly in the banking system and Greece is no exception to this. The domestic banking sector shrank dramatically during the last decade, the penetration of the Greek banks into foreign markets not only decelerated but was not at all considered as an option as almost all systemic banks operating abroad were forced to liquidate their foreign subsidiaries in order to rescue their domestic network, the reputation of the entire banking system lost momentum as depositors retracted massively their savings and finally all Greek banks found themselves bereft of private funds in order to avoid bankruptcy.

Summarizing the causes of the Greek banking crisis, we grouped them into three categories. The first contains the macroeconomic factors, the second the bank-specific factors and the third the factors that are not easily measurable. According to the first category, we found strong evidence of the significant involvement of almost all macroeconomic variables in the Greek banking crisis. With regard to bank-specific factors, the capital quality (EQ_TA, T1R), the banking liquidity (NL_DE) and the operational efficiency (PE_OI, NIM, NPLR, PERS, BRAN) seem to have played significant role in the Greek banking system's shrinkage. The third category includes ethical, political and social factors such as the moral hazard from both sides (banks and customers) and political instability.

We conclude that the origins of the Greek banking system collapse are a mix of complicated factors that can be found in a culture that has transformed the Greek economy from a production-base into a consuming-based one. However, consumption increases without the simultaneous growth in production can lead to imbalances and deficits. Unfortunately, the Greeks have used to live above the limits of their economic capacity and a large gap was created between production and consumption that was financed with additional debt. But this anemic welfare could not last forever. Usually, a crisis comes to remind us that we have 
to change our economic behavior and to reorient our needs in order to achieve the perpetual development.

The future perspectives of the Greek banking system are not so optimistic. The Greek banks seem unable for the moment to play a significant role and guarantee the future development of the Greek economy. As the problem with NPLs remains, the banks are not able to provide the necessary funds that the real economy demands. They seem to be trapped into a vicious circle where borrowers' protection increases the NPLs, the increased NPLs in turn impair the banks' capital adequacy and increase the systemic risk. The development of the entire economy remains extremely weak and fragile and thus, even more borrowers fail to pay their loans. The NPLs continue to increase and so on. As a result, the involvement of banks in the economy is restricted in unproductive activities. On the optimistic side, the Greek banks achieved to develop some different forms of interaction with their customers. Due to the banking lockdown of 2015, and the more recent covid-19 restrictions, the banking customers used internet and mobile banking in order to execute their daily transactions. This could be a good starting point for the banks to redefine the way they interact with their customers and thus to restructure their branch network to more efficient shapes. Hopefully, the Greek banking system will be soon in position to fulfill its mandate towards both the business ventures and individual customers.

Since in periods of crisis the role of State is of critical importance (Fronzaglia et al., 2019), our research has some policy recommendations to offer. Providing the effects of macroeconomic indicators for the banking system, it seems that large swings in economic activity, inflation, unsustainable debt levels and financial markets' volatility endanger risks and undermines the efficiency of the financial sector. Maintaining macroeconomic stability therefore is a prerequisite for a stable banking system. In addition, stress tests should be more often introduced as a recognition of the need to take a dynamic view of capital. Finally, it is advised that regulators should not impose needless burdens on banks, in cases where these have been proven counterproductive, i.e., reduce profitability without offsetting benefit.

\section{Conflicts of Interest}

The authors declare no conflicts of interest regarding the publication of this paper.

\section{References}

Abreu, M., \& Mendes, V. (2001). Commercial Bank Interest Margins and Profitability: Evidence from Some EU Countries. Pan-European Conference Jointly Organised by the IEFS-UK \& University of Macedonia Economic \& Social Sciences, 34, 17-20.

Alexiou, C., \& Voyazas, S. (2009). Determinant of Bank Profitability: Evidence from the Greek Banking Sector. Economic Annals, 182, 93-118.

https://doi.org/10.2298/EKA0982093A 
Apergis, N. (2021). The Role of Fiscal Policy in the Link between Income Inequality and Banking Crises. Applied Economics Letters, 28, 1283-1287.

https://doi.org/10.1080/13504851.2020.1808570

Asimakopoulos, I. G., Brissimis, S. N., \& Delis, M. D. (2008). Efficiency in the Greek Banking System and Its Determinant Factors. Bank of Greece Economic Bulletin, 30, 7-34. (In Greek)

Athanasoglou, P., Georgiou, E., \& Staikouras, C. (2008). Assessing Output and Productivity Growth in the Banking Industry. Bank of Greece, Working Paper, No. 92.

Balaban, N., Belić, K., \& Gudelj, M. (2011). Business Process Performance Management: Theoretical and Methodological Approach and Implementation. Management Information Systems, 6, 3-9.

Barrell, R., Karim, D., \& Ventouri, A. (2017). Interest Rate Liberalization and Capital Adequacy in Models of Financial Crises. Journal of Financial Stability, 33, 261-272. https://doi.org/10.1016/j.jfs.2016.09.001

Berger, A. N. (1995). The Relationship between Capital and Earnings in Banking. Journal of Money, Credit and Banking, 27, 432-456. https://doi.org/10.2307/2077877

Bosilj-Vuksic, V., Milanovic, L., \& Indihar-Stemberger, M. (2008). Organizational Performance Measures for Business Process Management: A Performance Measurement Guideline. In Tenth International Conference on Computer Modeling and Simulation (pp. 94-99). IEEE. https://doi.org/10.1109/UKSIM.2008.114

Chortareas, G., Girardone, C., \& Ventouri, A. (2009). Efficiency and Productivity of Greek Banks in the EMU Era. Applied Financial Economics, 19, 1317-1328. https://doi.org/10.1080/09603100802599506

Demirguc-Kunt, A., \& Huizinga, H. (1999). Determinants of Commercial Bank Interest Margins and Profitability: Some International Evidence. World Bank Economic Review, 13, 379-408. https://doi.org/10.1093/wber/13.2.379

Eijffinger, S. C., \& Karataş, B. (2020). Together or Apart? The Relationship between Currency and Banking Crises. Journal of Banking \& Finance, 119, Article ID: 105631. https://doi.org/10.1016/j.jbankfin.2019.105631

Fronzaglia, M., de Moura Júnior, Á., Racy, J., \& Vartanian, P. (2019). Possible Effects of Economic Public Policies Implemented in Brazil after the Financial Crisis of 2008 on Foreign Direct Investment. Theoretical Economics Letters, 9, 2800-2823.

https://doi.org/10.4236/tel.2019.98176

Gökhan, I., \& Esra, E. (2017). Analysis of the Effect of Developments in Banking Sector on the Economic Development: The Case of Turkey. In New Challenges in Banking and Finance (pp. 153-170), Springer, Cham.

Halkos, G., \& Salamouris, D. (2004). Efficiency Measurement of the Greek Commercial Banks with the Use of Financial Ratios: A Data Envelopment Analysis Approach. Management Accounting Research, 15, 201-224. https://doi.org/10.1016/j.mar.2004.02.001

Heffernan, S. (2005). Modern Banking. John Wiley \& Sons.

Hernaus, T., Bach, M. P., \& Bosilj-Vuksic, V. (2012). Influence of Strategic Approach to BPM on Financial and Non-Financial Performance. Baltic Journal of Management, 7 , 376-396. https://doi.org/10.1108/17465261211272148

Hondroyiannis, G., Lolos, S., \& Papapetrou, E. (1999). Assessing Competitive Conditions in the Greek Banking System. Journal of Financial Markets, Institutions and Money, 9, 377-391. https://doi.org/10.1016/S1042-4431(99)00017-7

Hsiao, C. (1985), Benefits and Limitations of Panel Data. Econometric Reviews 4, 121-174. 
https://doi.org/10.1080/07474938508800078

Jutasompakorn, P., Brooks, R., Brown, C., \& Treepongkaruna, S. (2014). Banking Crises: Identifying Dates and Determinants. Journal of International Financial Markets, Institutions and Money, 32, 150-166. https://doi.org/10.1016/j.intfin.2014.05.004

Kauko, K. (2014). How to Foresee Banking Crises? A Survey of the Empirical Literature. Economic Systems, 38, 289-308. https://doi.org/10.1016/j.ecosys.2014.01.001

Khan, A. H., \& Dewan, H. (2014). Measuring the Severity of a Banking Crisis and Finding Its Associated Factors: How Are the Factors Different for Simple and Severe Banking Crises? Theoretical Economics Letters, 4, 857. https://doi.org/10.4236/tel.2014.49109

Klevmarken, N. A. (1989), Panel Studies: What Can We Learn from Them? European Economic Review, 33, 523-529. https://doi.org/10.1016/0014-2921(89)90131-1

Kohlscheen, E., Murcia, A., \& Contreras, J. (2018). Determinants of Bank Profitability in Emerging Markets. BIS Working Paper No. 686.

Kosmidou, K. (2008). The Determinants of Banks' Profits in Greece during the Period of EU Financial Integration. Managerial Finance, 34, 146-159. https://doi.org/10.1108/03074350810848036

Kosmidou, K., \& Zopounidis, C. (2008), Measurement of Bank Performance in Greece. South-Eastern Europe Journal of Economics, 1, 79-95.

Kosmidou, V. K., \& Spathis, T. C. (2000). Euro and Profitability of Greek Banks. European Research Studies, 3, 43-56.

Kueng, P. (2000). Process Performance Measurement System: A Tool to Support ProcessBased Organizations. Total Quality Management, 11, 67-85.

https://doi.org/10.1080/0954412007035

Louzis, D., \& Vouldis, A. (2015). Profitability in the Greek Banking System: A Dual Investigation of Net Interest and Non-Interest Income. Bank of Greece, Working Paper, No. 191.

Menicucci, E., \& Paolucci, G. (2016). The Determinants of Bank Profitability: Empirical Evidence from European Banking Sector. Journal of Financial Reporting and Accounting, 14, 86-115. https://doi.org/10.1108/JFRA-05-2015-0060

Mylonidis, N., \& Kelnikola, I. (2005). Merging Activity in the Greek Banking System: A Financial Accounting Perspective. Southern Eastern Europe Journal of Economics, 1, 121-144.

Pedro, C. P., Ramalho, J. J., \& da Silva, J. V. (2018). The Main Determinants of Banking Crises in OECD Countries. Review of World Economics, 154, 203-227.

https://doi.org/10.1007/s10290-017-0294-0

Petrakis, P. (2012). The Greek Economy and the Crisis: Challenges and Responses. Springer-Verlag. https://doi.org/10.1007/978-3-642-21175-1

Petria, N., Capraru, B., \& Ihnatov, I. (2015). Determinants of Banks' Profitability: Evidence from EU 27 Banking Systems. Procedia Economics and Finance, 20, 518-524. https://doi.org/10.1016/S2212-5671(15)00104-5

Provopoulos, G. (2014). The Greek Economy and Banking System: Recent Developments and the Way Forward. Journal of Macroeconomics, 39, 240-249.

https://doi.org/10.1016/j.jmacro.2013.09.016

Rezitis, A. N. (2008). Efficiency and Productivity Effects of Bank Mergers: Evidence from the Greek Banking Industry. Economic Modelling, 25, 236-254.

https://doi.org/10.1016/j.econmod.2007.04.013

Sayilgan, G., \& Yildirim, O. (2009). Determinants of Profitability in Turkish Banking Sec- 
tor: 2002-2007. International Research Journal of Finance and Economics, 28, 207-214.

Van Looy, A., \& Shafagatova, A. (2016). Business Process Performance Measurement: A Structured Literature Review of Indicators, Measures and Metrics. SpringerPlus, 5, 1-24. https://doi.org/10.1186/s40064-016-3498-1

Vom Brocke, J. (2007). Service Portfolio Measurement: Evaluating Financial Performance of Service-Oriented Business Processes. International Journal of Web Services Research, 4, 1-32. https://doi.org/10.4018/jwsr.2007040101

Wu, H. Y. (2012). Constructing a Strategy Map for Banking Institutions with Key Performance Indicators of the Balanced Scorecard. Evaluation and Program Planning, 35, 303-320. https://doi.org/10.1016/j.evalprogplan.2011.11.009 